\title{
Culture, Competence and Intercultural Competence: Global and Local Diversities in Intercultural Discourse
}

\begin{abstract}
Despite the plethora of definitions and models of intercultural competence (IC), researchers still face challenges, among which bridging gaps between worldwide trends and local flows in intercultural discourse appears to be an essential goal if definitions and models of IC are to be exhaustive. The present paper summarizes trends in approaches to competence, culture and IC as presented in two types of discourse, global and local, pointing to incongruities between the two viewpoints. An analysis of intercultural research reveals that as opposed to global discourse, which is holistic in nature, local discourse is more modular. It remains an empirical question how these two discourses, and the centripetal and centrifugal forces that come with them, will permeate each other. Thus, the analysis highlights the need to enhance communication among researchers in order to manage multiple approaches, both global and local, and incorporate them into intercultural discourse.
\end{abstract}

\section{Keywords}

competence, culture, intercultural competence, global and local discourses

\section{Introduction - intercultural competence and complexity theory}

Although the notion of intercultural competence (IC) has been the topic of interdisciplinary debate for decades now, its nature is still far from defined and ways of development far from delineated. In fact a recent monograph on the state of the art in intercultural research (see Deardorff 2009) reveals that the multitude of existing interpretations of the concept not only fails to resolve the more familiar dilemmas, including the degree to which recurrent elements of competence, i.e. motivation, knowledge and skills, should be approached in a discrete manner (2009: 35), or ways in which the stable and the developmental could be compromised (Bennett 1986), but also poses new challenges, among which the need to bridge gaps and construct models on the basis of existing local patterns rather than a priori global stabilities seems particularly timely. Recent publications (e.g. Dervin 2011, Sorrells 2014) strongly emphasize that global discourse has dominated intercultural communication and highlight the need for re-defining the concept of culture, the linkage between global and local discourses and the positioning of intercultural communication in research. ${ }^{1}$ Furthermore, "synthesizing research from multiple disciplines and cultures into a coherent whole" (2011: 24) is the course of action advocated in the UNESCO Conceptual and Operational Framework on Intercultural Competences.

1 Local discourse is understood as texts created in and influenced by particular national backgrounds and academic positions; local/national discourses tend to convey specific concepts typical of a given locality and rendered in its native language. Global discourse is understood as texts created by researchers coming from various national backgrounds and sharing an international language, typically English. Their common communicative ground facilitates the exchange of ideas and may result in the emergence of universal concepts of generic nature. The bridge between the local/national and the global/international could take the form of a holistic (transnational) paradigm (Risager 2007), whereby the two discourses would constitute its respective micro and macro levels.

\footnotetext{
* Ariadna Strugielska \& Katarzyna Piątkowska Department of English

Nicolaus Copernicus University, Toruń, Poland

ul. W. Bojarskiego 1

87 - 100 Toruń, Poland

Ariadna.Strugielska@umk.pl-kapia@umk.pl
} 
Recent tendencies in international intercultural research have been summarized in a number of publications, including Deardorff's (2006) synthesis of expert conceptualizations of IC, Spitzberg and Changnon's (2009) overview of contemporary theories and models, or Dai and Chen's (2014) attempt to capture patterns in the evolution of IC. Endeavors to establish regularities at the theory level in the form of supradisciplinary models have also been undertaken, and it seems that the ecological perspective, informed by complexity theory, has become a particularly influential approach here (see Baker 2015 for a discussion). To be more specific, recent studies (e.g. Foncha and Sivasubramaniam 2014, Moeller and Nugent 2014, Rygg 2014, McBride and Gu 2015) point to instability, variability, unpredictability, aperiodicity, and non-linearity in the acquisition of IC. Thus, IC is viewed as an emergent category affected by variables which undergo changes and permeate one another, forming complex systems. Recognizing the nature of IC's development, Strugielska and Piątkowska (2017) point to congruence between IC and the theory of complex systems.

Complexity theory is an overarching explanation of both real-world phenomena and scholarly work, which aims to account for how elements of a system interact to become a new whole, with its emergent attributes and dimensions. Since complex systems have been already extensively discussed and applied (see Larsen-Freeman and Cameron 2008 for an overview), their architecture and basic terminology will not be revised but simply acknowledged. Still, since a complex systems perspective tends to concentrate on particular elements and contingencies which show "which aspects of context are most salient to solving the problems at hand" (Phipps and Levine 2011: 9), it needs to be declared that in the current discussion we evoke the following aspects of complexity theory: attractor states, i.e. stabilities - fixed, cyclic or chaotic - preferred by the system, the state space, delineated by the system's movement between or among the attractors and delimiting its scope of possibilities, and levels, i.e. micro and macro, as well as timescales, i.e. current and developmental, on which a complex system can be examined (Larsen-Freeman and Cameron 2008: 57-61).

Likewise, drawing from the view of discourse as a flow of written or oral texts through time (Risager 2007: 18), we recognize local and global discourses as (potentially) interrelated. Following the theory of complex systems, we demonstrate that each type of discourse mentioned above is characterized by its own stabilities, i.e. attractors - various components constituting culture, competence and IC - which have emerged through a decade of intercultural research. We argue that these attractors function as centripetal and centrifugal forces, delimiting the interface between the two discourses under consideration and leading to inconsistency in the way IC is viewed as a whole.

Consolidating various characterizations of IC unavoidably leads to simplifying and essentializing this inherently complex notion and putting forward universal tendencies, predominantly in the form of deductive models. Such top-down attempts, however, have not received support from studies focused on more limited contexts of IC, including discourse and culture-specific perspectives (see, for instance, Deardorff 2009). While generalizations are an intrinsic part of any theory or model, a contemporary position of intercultural research seems to be leaning towards experiential stabilities, variable patterns and global regularities emerging from local contexts rather than shaping them.

In consonance with this bottom-up, inductive propensity, we theorize IC as a complex system at two levels and in two contexts. First, at a micro level, (inter)culturality and competence will be characterized as dynamic and emergent phenomena. Importantly, and unlike previous research based on complexity theory (e.g. Kramsch 2011, Baker 2015), the intricacy of culture and competence will be viewed as a natural consequence of the ways the two concepts have been theorized. This evolutionary perspective will show how apparently incompatible conceptualizations of culture and competence in the relevant literature of a given period can indeed be reconciled as new wholes if stabilities are redefined and levels and timescales acknowledged. These findings are then consolidated at a macro level, whereby IC is seen as emerging from its component cat- 
egories, i.e. (inter)culture and competence. It is argued that the conceptual scaffolding provided by the two donor concepts is gradually removed and consequently, the experiential stabilities proposed at the micro level, i.e. in the theories of culture and competence, may emerge as evolved, novel categories at the macro level, i.e. in the characterizations of IC. To illustrate, while social norms, customs and values, which characterize early models of IC, may be directly related to their source category - culture - adaptability, responsiveness or disclosure, which, according to Chen (2014: 18), appear in more contemporary descriptions of the notion, can hardly be attached to a single donor category. Instead, IC has come to constitute "a whole that is more than the sum of its parts and that cannot be explained reductively" (Larsen-Freeman and Cameron 2008: 59). Wholeness characterizes complex systems at higher, more advanced stages of evolution, and we demonstrate that unity indeed permeates a number of contemporary conceptualizations of IC. This argument will be supported with recent findings from cognitive psychology, and the concept of a simulator (Barsalou 1999, 2003, 2016), will be proposed as a wholeness possibly characterizing the most advanced evolutionary stage of IC.

Simultaneously, following a recent call for a balance between global and local perspectives as a nexus in intercultural research (Liu 2012), we highlight two types of discourse, with reference to which IC could be characterized, i.e. global, where results are published in English and can thus easily reach and influence international audiences, and local, where results are published in a native language other than English and can therefore influence a limited number of intercultural researchers (Risager 2007). Consequently, we emphasize that intercultural dialogue between researchers is the basis for IC.

Following the urge to make pluralities and diversities "serve as the beginning points for developing...common definitions and creating a new space of interactions" (UNESCO 2011: 45), out of which a new understanding of IC may arise, we investigate a local discourse, i.e. interpretations of (inter)culture, competence and IC emerging from the narratives of Polish academics whose research results have influenced the Polish intercultural scene for the last decade, and juxtapose our findings with a propensity towards wholeness which seems to have had a considerable impact on intercultural research conducted on the international scene. Taking the nature of emergent stabilities, i.e. favored concepts and theories, as our criteria for comparison and acknowledging constant interaction between "centripetal and centrifugal forces" (Bakhtin 1981: 272), or the reciprocal nature of causality (Thompson and Varela 2001), we finally wonder if or how national and international visions of IC might influence each other in future research, stressing the need for intercultural communication between researchers, which is the basis of an integrative approach to intercultural investigations.

\section{Culture, competence and IC in global discourse}

Looking at the plethora of existing conceptions of IC, it is a truism to say that its constitutive categories have been given various interpretations, oscillating between the solid and the fluid, the mentalistic and the social, the individualistic and the collective, the universal and the relative, and that leaning towards either end of this continuum has had repercussions for understanding IC as a whole. Importantly, these apparently contradictory positions have been supported by interdisciplinary findings, encompassing research in applied linguistics and ecolinguistics, sociology and sociocultural studies, cultural and translation studies, to name but a few (for a complementary list see, for instance, Matsuo 2012). If indeed the existing variety of theories and notions used to build the intercultural framework at the global level has sound foundations, there is a need for an overarching explanation in order to account for apparently incompatible accounts, and complexity theory, embracing the fixedness of the structuralist tradition and the hybridity of the postmodern approach as a reconstructed wholeness, is an attractive option. 


\subsection{Approaches to culture in global discourse}

When looking at the idea of culture in global intercultural research, most studies depict the concept in terms of its products, or "objective facts" (Deardorff 2009: xiii), and although the interpretation of culture as "a shared, stable living space, supported equally by all members of the group, which passes it onto the next generation" (UNESCO 2011: 7) is distant from the reality of the globalized world, it still seems to permeate intercultural discourse. For instance, Larzén (2005) notes that the cognitive orientation to culture, based on factual knowledge and information, far surpasses its conceptualization inspired by what she defines as the affective orientation - a holistic approach to culture seen as a bi-directional perspective, where empathy and respect for otherness are encouraged (2005: 145). Much in the same vein, Tournebise (2012: 114) concludes that narratives of educators involved in intercultural training are "closer to a culturalist interpretation", whereby cultures are treated as collections of facts and thus comparisons are easy to make and discrepancies easy to spot. This differentialist, solid approach to culture (Dervin 2010) facilitates categorical classifications, contributes to the emergence of stereotypical discourses, and prevents genuinely intercultural encounters. i.e. exchanges based on flexibility, heterogeneity and mediation, or liquidity (Bauman 2004). Similarly, Matsuo (2014: 19) cautions against the objectification of culture into abstractions which can easily become "a degenerate form of representation: the stereotype". In fact, if cultures are viewed in an ethnocentric, "container-like" fashion, intercultural dialogue is likely to falter and ultimately freeze into an impenetrable whole (2014: 18). This conception of culture underlies a number of definitions of interculturality, among which Byram's (1997) model seems a classic example (see Matsuo 2012, 2014 for details). While focusing on the products of culture seems cognitively plausible since, as Matsuo (2014: 18) argues, reified abstractions are "stable and held easily in cognition" and may provide "invaluable windows into understanding a culture" (Deardorff 2009: xiii), such knowledge needs to be substituted by or complemented with a dialogic approach, whereby culture is seen through its complexity and instability. The former option, i.e. replacing the solid with the liquid, is elegantly captured through Dervin's (2010) Janusian perspective, which implies mutual excludability of the two conceptions. Likewise, Matsuo's (2014: 19) proposal, oscillating between the dialogic and the monologic, finally settles on a dichotomous approach, whereby culture can be theorized in either cognitive, i.e. stable, or linguistic, i.e. relative, terms, with the latter being consistent with a culture-as-discourse perspective. The second alternative, i.e. supplementing the liquid with the solid, seems to transpire from Kramsch's (2011: 18) interpretation of culture as "something that people carry with them in their heads", as myths and metaphors which have become commodities. This apparently reified view of culture is, however, strongly relativized through "symbolic codes and discourses, habits of the mind and habits of the heart, values, philosophies and ideologies" (2011:24), which replace national customs and historical facts, and which might counteract "fears of undue stereotyping" (2011: 18). Ultimately then, culture is a category of thought which, in intercultural encounters, needs to be negotiated as "speakers grapple with each other's categorizations of events and underlying ideologies" (2011: 15) and interculturality becomes a transcultural ability to operate between languages and cultures and to create a third culture - "a symbolic process of meaning-making that sees beyond the dualities of national languages and national cultures" (Kramsch 2010: 1). Consequently, culture becomes a transcultural flow which requires a mindset that would optimize understanding symbolic values, reframing the familiar in order to create "alternative realities" and "looking at and through language" (2009: 201).

To sum up, perspectives on culture within global intercultural discourse oscillate between reified and processual interpretations, with the former anchored in degenerate and detached representations and the latter drawing on the subjective and the relative, on the awareness of symbolic values and the recognition of previous discourses. Much as these two extreme positions could be the preferred interpretations of (inter)culturality, constituting a kind of a cyclic attractor, there is also the middle way, where observable stabilities result from development, where there is variability within permanence, and where constancy is always relative and dependent on the strength 
of an attractor (Larsen-Freeman and Cameron 2008: 56). When culture self-organizes as a general cognitive and affective orientation of the self, a relational frame of mind, or "a mode of belonging" (Kramsch 2009: 247), unwarranted and vacuous representations are transformed into attractors, e.g. stereotypes and facts, cultural frames and models, cultural metaphors and symbols as well as individual realities, which, although apparently stable, are indeed dynamic and prone to change. These sedimentations, reflecting emergence at different levels and timescales, will evolve further when coupled with other systems and contexts. Thus, while Collier (1989) rightly notes that the way culture is defined fundamentally shapes the conceptualization of IC, from the complexity perspective, IC is also influenced by the way competence is characterized.

\subsection{Approaches to competence in global discourse}

To begin with, as Byrnes (2006) observes, the notion of competence unavoidably echoes the theoretical burdens of the structuralist tradition and evokes an unmotivated competence/performance dichotomy. Indeed, as Matsuo (2014: 19) argues, this division can be perceived in Byram's (1997) cognitive interpretation of competence in terms of knowledge, behaviours, attitudes and skills, which she contrasts with a dialogical position, whereby "knowledge and actions are conceptualized linguistically". Hence, competence is viewed as a Janusian concept, which is either cognitive, i.e. located inside an individual and thus "too rational, too conscious, and too intentional" (Spitzberg and Changnon, 2009: 35), or relational, i.e. "active, responsive, creative, 'emotional-volitional" (Matsuo 2014: 18). In other words, the cognitive perspective on competence presupposes either excluding certain important notions from an overall representation, including emotional and physiological aspects, or characterizing these elements, e.g. anxiety or motivation, as cognitive, i.e. stable, fixed and retrievable categories. Another consequence of a dichotomous perspective on competence in intercultural research is adopting a modularity, or dimensionality, position, whereby motivation, knowledge and skills - the core components of IC (Spitzberg and Cupach 1984) - are taken as separated. Throughout the history of global intercultural research, this classic triad has been supplemented by other notions, such as awareness, context, or outcomes (see Dai/Chen 2014 for an overview), all of which have been metonymically captured as traits, e.g. tolerance, flexibility, patience, a sense of humor, adaptability, curiosity, empathy, a clear sense of self, or tolerance of ambiguity (Fantini/Tirmizi 2006). In fact, as Spitzberg and Changnon (2009: 6) argue, certain features of competence, e.g. understanding, co-orientation, satisfaction or adaptation, have functioned as its synonyms, and "empathy, perspective taking, and adaptability continue to serve as the hallmarks of most models of IC, regardless of the cultural origins of the authors" (2009: 44). In the same vein, Deardorff (2011) enumerates six recurrent criteria of competence, which are: respect, self-awareness/identity, seeing from other perspectives, listening, adaptation, relationship building, and cultural humility. In fact, metonymic representations of competence have led to its alternative conceptualizations as, for instance, (cross-cultural) effectiveness (Kealey 1989) or (intercultural) sensitivity (Bennett 1986). A remaining challenge for intercultural researchers, however, is how to account for these emergent features of competence with reference to levels or scales. For instance, according to Spitzberg and Changnon (2009: 35), sensitivity is a subcomponent of adaptability which, in Dai and Chen's (2014) view is itself a component of social adjustment, while Deardorff (2011) interprets adaptation as a prerequisite for IC. In an attempt to overcome this confusion alternative terminology has been proposed, with the notion of capacity, or abilities, offered as a possible solution. According to Phipps/Levine (2011: 11), capacity is "the disposition for action, not just about how well someone can do something but with competences subsumed beneath it"; it is "the capacity for creativity and collaboration". Our solution is to refer the variety of interpretations that competence has received to the system of human abilities.

To begin with, a number of metonyms for competence in fact refer to basic cognitive skills, which, according to Tomasello (2003), are pattern-finding and intention-reading abilities, with the latter consisting of three interrelated phenomena: joint attention frames, the understanding of 
communicative intentions and role reversal imitation. Intention-reading abilities seem to empower such features of competence as co-orientation, social adjustment, perspective taking or empathy. Importantly, according to Barsalou $(2003,2009)$, intention-reading abilities lead to inferences about object affordances, the effectiveness of actions and possible emotional rewards and hence, they become a scaffolding for the conceptual system. Analogically, certain features of competence, e.g. co-orientation or perspective taking, are a scaffolding, or a set of prerequisites, for more abstract, i.e. emergent, traits, e.g. adaptation or sensitivity. While the exact nature of these interdependencies needs further research, what transpires from the present perspective is an evolutionary nature of competence, i.e. its tendency for development and emergence. In this framework, capacity, i.e. a new term for competence, may indeed be built on capabilities which adapt in response to change, i.e. the growing demands of globalized contexts.

If this non-modular and dynamic cognitive perspective on competence is valid, it should also consolidate interpretations which view knowledge, skills, emotions, attitudes and actions as separate components of IC. Indeed, Barsalou's (1999) characterization of cognition, which depends on perception, action and interception and couples with the physical and social environment, validates redefining competence as a category encompassing elements of objects, settings, self relevance, physical actions, and a variety of cognitive, affective and bodily responses. If seen from this perspective, the previously separated components of competence become dimensions of multimodal conceptualizations. This approach is consistent with Kramsch's notion of symbolic competence, which is "engaged in the symbolic power game of challenging established meanings and redefining the real" (2010: 359), in that established meanings are the fixed categories of the mind, characteristic of structuralist approaches, while redefined meanings are conceptualizations, or situated simulations (Barsalou 2009), which "are likely to be incomplete and distorted in many ways, representing abstractions, caricatures, and ideals, as well as specific learning episodes" (Barsalou 2016: 3). Recurrent elements of such conceptualizations can be abstracted as frames or schemas, and these statistically relevant configurations become records of past experiences, or points of emergence, which Barsalou (2008) calls simulators. If a simulator, or a cognitive frame, is re-activated, it gives rise to a potentially infinite set of simulations, i.e. conceptualizations. If reenacted in specific contexts, frames emerge as cultural models, social abstractions and stereotypes, conceptualizations constrained at personal or discourse levels. Consequently, simulators may be taken as our general cognitive potential which enables categorization, supports action and provides people with "diverse forms of expertise about perceived category instances" (Bruner 1973 quoted in Barsalou 2016: 1), i.e. competence. If re-activated in a particular context or culture, competence is elaborated as a particular assembly of simulators, or their dimensions, or simply a frame of mind. Ultimately then simulators, i.e. the new wholes emerging from the co-adaptation of context (culture) and cognition (competence), are much simpler and, simultaneously, more advanced, than the complexities beneath them.

Characterizing culture and competence from a complex systems perspective can be done at two levels. At the micro level the concepts of culture and competence will display features of complexity, which in turn will be reflected in the way they are theorized. Essentially, if complexity is the model, dichotomies, e.g. the solid and the fluid or the universal and the relative, will interact and emerge as relative though constrained dynamic stabilities. At the macro level, IC, a complexity emerging from its two donor categories, will be viewed as a whole which is less complex and more unified than its parts. We propose that this novel wholeness be a simulator which reenacts the ultimate unity of embodied and embedded cognition.

\subsection{Approaches to IC in global discourse}

The above proposal is consistent with recent unifying tendencies in the global intercultural paradigm. As Chen (2014: 17-18) demonstrates in his overview of intercultural research, the longheld dimensions of IC, e.g. cultural awareness or personal and psychological attributes, should indeed be replaced by less specialized, generic concepts, i.e. self-disclosure, self-consciousness, 
social adjustment or interaction involvement. "Indeed, many who encourage intercultural competences are coming to understand that people either are competent jointly, or are incompetent, but there is no such thing as one person being interculturally competent alone" (UNESCO 2013: 38).

If unification, wholeness and simplicity are indeed the driving forces of global intercultural research, leading to the emergence of IC at an evolved, advanced stage, it is intriguing to see if or how this tendency corresponds to elements of intercultural research highlighted in local discourse. This interface will be outlined with reference to the Polish perspective.

\section{Culture, competence and IC in local discourse}

Polish intercultural discourse has been chosen as a local discourse for the analysis since there is a lack of data regarding this perspective (Risager 2007) which, as the discussion below shows, is potentially influential. We may distinguish two tendencies which determine the understanding of the concepts of culture, competence and IC in the national discourse. The first one, a cognitive perspective, which is characterized by a differentialist approach to culture and IC and a structuralist approach to competence, defines the three notions as stable and modular concepts. A cognitive view can be juxtaposed with a new tendency, i.e. an attempt at a dialogic perspective, which represents a more dynamic approach to the notions of culture, competence and IC, typical of a constructivist perspective.

\subsection{Approaches to culture in local discourse}

To begin with, two approaches to culture, cognitive and dialogic, emerge from the local intercultural discourse. The majority of Polish researchers (e.g. Jabłońska 2008, Szczurek-Boruta 2013, Mihułka 2010, 2012, 2014, Więcek-Janka 2011) assume a cognitive perspective. Its supporters view culture as knowledge, assumptions and practices which allow distinguishing one culture from another. Since heterogeneity is acknowledged, the analysis of culture focuses on cross-cultural differences, which become the foundations of knowledge, abilities and attitudes of IC (e.g. Komorowska 1996), pointing to a dfferentialist perspective. Cross-cultural differences dominate all ranges of knowledge (see Komorowska's 1996 or Szczurek-Boruta's 2013) and the importance of cultural diversity is emphasized in knowledge of meanings held by people of various cultures or culturally shaped perceptions (Bandura 2007).

The other perspective on culture, a dialogic approach, stresses an individual dimension in its interpretation (e.g. Żydek-Bednarczuk 2012). This position is emphasized by Owczarek (2004), who concludes that the comprehension of culture is influenced by the feelings and intellectual aspirations an individual experiences. In this sense culture is viewed as a dynamic concept undergoing constant change which, rather than following a universal line, proceeds in an individual way. Furthermore, culture is always contextualized, i.e. cultural competence is always a consequence of a given situation, hence, variety is a norm. This is best summarized by WąsikiewiczFirlej, Szczepaniak-Kozak and Lankiewicz (2012), who consider culture with reference to pragmatic competence and situational context, concluding that frequent heterogeneous exposure to cultural experience may enhance adaptability, resourcefulness and perceptiveness. In the same vein, Owczarek (2004) reflects on the interface between the cultural aspects an individual experiences and an attitude they take. Thus, the dialogic perspective presupposes a subjective and relativist position in the interpretation of culture. However, this perspective does not reject a modular view, which considers knowledge, skills or assumptions as components of culture and IC. Such an approach is taken by, e.g. Owczarek (2004), who distinguishes between knowledge, skills and attitudes, which are based on comparing and contrasting cultures. Similarly, Żydek-Bednarczuk (2012), Wąsikiewicz-Firlej et al. (2012) introduce a modular view of culture, where abilities, awareness and competences are referred to culture and influence the quality of IC. Therefore, the two perspectives on culture, differentialist and dialogic, cannot be treated as contradictory. 


\subsection{Approaches to competence in local discourse}

There are also two tendencies in the way the concept of competence in the national intercultural discourse is approached, i.e. a structuralist and a dialogic position. The former is based on a dichotomy between competence and performance while the latter results from an experiential and individualist approach. However, regardless of the approach adopted, researchers enumerate various criteria of competence, which are its equivalents. These include: knowledge (Jabłońska 2008, Szczurek-Boruta 2013), savoir (Komorowska 1996), skills (Jabłońska 2008, Rapacka 2009), motivation (Jabłońska 2008), and attitude (Białek 2009). Therefore, the same criteria which are considered to be the elements of competence are also the components of IC. Researchers following Byram's (1997) model of IC understand competence in terms of a dichotomy between competence and performance with the former referring to factual general and culture-specific knowledge, self-awareness, awareness of otherness and the latter relating to skills and attitudes resulting from this knowledge, i.e. skills of observing, discovering, analyzing, interpreting, relating, and evaluating and attitudes of open-mindedness and empathy. Hence, competence includes cognitive (knowledge) and functional (the skill of applying this knowledge) elements. The interface position, i.e. the interrelation between competence and performance, is at the same time emphasized. However, while knowledge affects skills and attitudes, it remains unaffected by them. In most discourse (e.g. Komorowska 1996, Szczurek-Boruta 2013, Jabłońska 2008) there is predominance of competence over performance. As a consequence, knowledge is treated as central and necessary to attain communicative competence; it is a prerequisite of effective communication, which is treated as a by-product of competence. For example, Komorowska (1996) treats competence in terms of separate categories, distinguishing between knowledge of facts and knowledge understood as the ability both to adapt (including attitudes and acting appropriately in a given situation), and to analyze phenomena. In the same vein, Jastrzębska (2005) distinguishes between declarative and procedural knowledge. Declarative knowledge refers to knowledge of facts and awareness while procedural knowledge relates to perception and ability. Szczurek-Boruta (2013) presents a similar approach to competence. Namely, she introduces four types of knowledge: knowing about (gathering knowledge), knowing how (the ability to act appropriately verbally and non-verbally - in a given context), knowing why (discovering and understanding), and knowing oneself (reflecting). Similarly, Jabłońska (2008) enumerates the following components of competence: knowledge (of facts), motivation (readiness to cooperate with others), and abilities (to empathize and to adapt). Competence, therefore, means having a sufficient amount of knowledge to sanction an appropriate skill. In other words, performance depends on competence and is affected by it. Such an interpretation of competence presupposes the transferability of abilities from knowledge to skills and attitudes, with the three components viewed as separate. In other words, the supporters of this approach do not take into consideration a situation or context as a factor influencing the development of competence, which lets us conclude that competence is treated as an autonomous faculty in the human mind. It is thus typical of the structuralist view, whereby competence is a set of stable and fixed categories understood as general abilities based on knowledge, skills, emotions, and attitudes. However, it has to be stressed that Polish researchers are not unanimous about the degrees of autonomy the components of competence may display. For example, Komorowska (1996) and Szczurek-Boruta (2013) view knowledge as the core components of IC, pervading other components. Wilczyńska (2005) considers personality features among the most essential elements of IC since they influence individuals' ability to act in intercultural situations and themselves are affected by knowledge, abilities and individual factors. Another feature of the structuralist perspective upon competence is its approach to the nature of interaction and its role in IC. Interaction is one of the elements of competence. It refers to the ability to transfer interactive skills in one's native culture to a new cultural context. From this perspective the ability of effective interaction is placed alongside other components of competence, especially in the development of IC. 
A dialogic approach to competence views the concept as a more complex notion referring to an ongoing process of changing personality and self-awareness, which leads to changes in knowledge, skills and attitudes, emphasized in IC (Białek 2009). The outcome of this process is affected by a situation, which influences the levels and degrees of competence. Thus, the perspective rejects the view of competence as a set of fixed stabilities. Instead, it presents the notion as a fluid category approached through a more constructivist tradition, i.e. meaning construction. This interpretation is represented by Owczarek (2004), who notices that the development of IC is an individual process affected by personal emotions and mental processing; these are transformed into the interpretations of culture; i.e. the development of competence is based on personal meaning construction. Another difference between structuralist and dialogic perspectives is the way they view the role of interaction with reference to competence. Despite the fact that in both interpretations competence and interaction are inseparable, the dialogic perspective sees the ability to interact as permeating all aspects of competence and working with them at all levels. Moreover, an important role of conscious reflexivity in developing IC (Białek 2009) means that competence is understood as an assembly of interfacing cognitive and affective domains, personality factors, a situation, verbal and behavioural reactions, which lead to changes in knowledge, skills and attitudes. As a result, the level of competence attained by various individuals may be different and unpredictable. Consequently, competence is interpreted in terms of sociolinguistic, pragmatic and psychological aspects. To conclude, although the two perspectives presented above interpret competence in different ways, in both views the concept is composed of linguistic, social and psychological phenomena, which, as Żydek-Bednarczuk (2012) notices, form a continuum. This continuum is interpreted either as a transfer of core elements of these phenomena (a structuralist approach) or as a an assembly of elements permeating one another (a dialogic approach).

\subsection{Approaches to IC in local discourse}

Recent intercultural research in Polish points to the interpretation of interculturality being dominated by a cognitive perspective with the focus on the direct application of Byram's (1997) model of IC (e.g. Jabłońska 2008, Szczurek-Boruta 2013, Mihułka 2010, 2012, 2014) or following this tradition (e.g. Więcek-Janka 2011). From this perspective IC is discussed with reference to its products, which are delineated as a collection of separate competences, i.e. knowledge, skills and attitudes, wherein these competences are a priori stabilities emerging from theoretical assumptions. Knowledge underlies IC and is treated as a stability embracing these competences. Consequently, the definition of IC as four types of knowledge prevails with savoir-etre referring to the ability to overcome ethnocentric attitudes, savoir-apprendre relating to the ability to analyze newly encountered cultural phenomena, savoir-knowledge of basic cultural facts, and savoir-faire as the ability to communicate with people of other cultures (Komorowska 1996). Although mainstream studies treat the development of IC as a dynamic and complex process, where particular competences may not only attain diverse levels in an individual but also change dynamically depending on a communicative situation (Mihułka 2012), researchers strive to establish elements or fixed entities which are viewed as requirements to attain IC. These are reminiscent of Byram's (1997) savoirs (see table 1 below for details). 


\begin{tabular}{|c|c|c|}
\hline Knowledge & Ability & Attitude \\
\hline $\begin{array}{l}\text { knowledge of one's own and } \\
\text { the target culture and } \\
\text { knowledge of people of other } \\
\text { cultures (Komorowska 1996, } \\
\text { Mihułka 2010, 2012, 2014), } \\
\text { which refers to the } \\
\text { knowledge of problems } \\
\text { arising from cross-cultural } \\
\text { interaction and the knowledge } \\
\text { of other people's perceptions } \\
\text { and attitudes }\end{array}$ & $\begin{array}{l}\text { ability to analyze newly } \\
\text { encountered cultural } \\
\text { phenomena (Komorowska } \\
\text { 1996) }\end{array}$ & $\begin{array}{l}\text { attitude of empathy, } \\
\text { tolerance, openness to others, } \\
\text { respect for cross-cultural } \\
\text { differences, the ability to } \\
\text { abandon ethnocentric } \\
\text { attitudes, to suspend } \\
\text { judgment and disbelief } \\
\text { (Ambrosewicz-Jacobs 2004, } \\
\text { Sobieraj 2012) }\end{array}$ \\
\hline $\begin{array}{l}\text { metacognitive reflection on } \\
\text { intercultural experiences and } \\
\text { observations (Sobieraj 2012, } \\
\text { Szczurek-Boruta 2013) }\end{array}$ & $\begin{array}{l}\text { ability to act properly when in } \\
\text { contact with other people, } \\
\text { which entails the ability to } \\
\text { adjust to a culturally new } \\
\text { situation (i.e. the ability to } \\
\text { communicate verbally and } \\
\text { non-verbally in a } \\
\text { multicultural environment) } \\
\text { (Komorowska 1996, } \\
\text { Aleksandrowicz-Pędich 2006, } \\
\text { Jabłońska 2008, Szczurek- } \\
\text { Boruta 2013) }\end{array}$ & \\
\hline $\begin{array}{l}\text { awareness of self-identity } \\
\text { referring to the ability to } \\
\text { reflect on the system of } \\
\text { values existing in one's own } \\
\text { culture which determine } \\
\text { human behaviour and ways of } \\
\text { discovering self-identity } \\
\text { (Sobieraj 2012, Szczurek- } \\
\text { Boruta 2013) }\end{array}$ & $\begin{array}{l}\text { ability to discover and } \\
\text { understand perception, values } \\
\text { and code of conduct typical } \\
\text { of a particular culture } \\
\text { (Szczurek-Boruta 2013) }\end{array}$ & \\
\hline
\end{tabular}

Table 1. Elements of IC

Thus, cross-cultural differences, the attitude of open-mindedness built on them, and skills of acting in a multicultural context respecting these differences lie at the heart of IC, which is understood as a by-product or a consequence of its particular competences.

This differentialist approach can be juxtaposed with studies representing a more dialogic perspective (e.g. Wilczyńska 2005, Białek 2009), where IC is discussed with reference to pragmatics and liquidity. Instead of being understood as a set of stable elements (e.g. competences), IC is viewed as a process of constant change and growth of personality and self-awareness, which requires strong motivation and emotional engagement (Białek 2009). Such an understanding of IC results from the interpretation of culture as an individual experience. This experiential and individualist approach finds its manifestation in Owczarek's (2004) assumption, who bases the analysis of IC on the experience an individual goes through. Rather than a consequence or a product of certain competences, i.e. knowledge, skills and attitudes, IC is described as a process leading to changes in knowledge, skills and attitudes. In this respect the development of this competence is dependent on immeasurable factors such as attitudes and opinions (Komorowska 1999). However, it has to be clearly stated that the modular nature of IC is not totally rejected in this approach. Researchers point to the importance of components which form the basis of a differentialist perspective, i.e. knowledge, skills and attitudes (e.g. Komorowska 1999, Białek 2009). A dialogic perspective assumes that these elements are dominated by other factors such as personality features or the attitude of openness towards otherness (e.g. Białek 2009). Similarly, in contrast to 
the representatives of a differentialist approach, researchers look for some commonalities unifying the whole framework of IC to account for the interface between the particular components of IC. For Rapacka (2009) it is general and language competence, through which intercultural education takes place. Wilczyńska (2005) considers personality features crucial since they influence knowledge, skills and individual aspects, i.e. opinions, emotions and the system of values. Majewska (2014) points to discourse competence as a detrimental factor in the development of IC. As a consequence, the attitude of openness and willingness to accept cross-cultural differences substitute knowledge as an encompassing aspect and form the foundations of IC (Białek 2009). Interculturality builds on pragmatic competence (Nikitorowicz 2010) discussed in terms of flexibility with which an interculturally competent speaker engages in cross-cultural interaction. Nikitorowicz (2010) stresses that IC cannot be considered in terms of mere coexistence of various cultures but in terms of a public space where various cultures interact without losing its identity. However, it is not context that is taken into consideration but a situation and verbal behaviour associated with it. Hence, different cultures require different reactions and the ability to execute appropriate verbal behaviour is associated with effective IC. Thus, IC is fostered through interaction. In the same vein, Rapacka (2009) maintains that the development of IC takes place together with the development of the ability to interact. Similarly, Majewska (2014) concludes that discourse competence is the most important decisive factor in the development of IC. Therefore, the dialogic perspective postulates the interpretation of IC as the ability to construct meaning in interaction with representatives of other cultures. The need for such an approach is pronounced by Zarzycka (2001), who discusses this competence in terms of negotiating meaning by bringing our attention to possible obstacles in cross-cultural interaction resulting from different perception and interpretation of meaning by various representatives of cultures. Hence, the development of IC goes along with the development of the ability to interact with others. This simultaneous growth is a necessary condition for the acquisition and transformation of knowledge, the development of one's personality and reflexivity, whereby conscious reflexivity is treated as the core of intercultural education and development (Białek 2009: 121).

\section{Conclusions}

Although the analysis of the local discourse of IC reveals the presence of two approaches to culture, competence and IC, they cannot be regarded as placed on the opposite ends of the continuum. Rather than being contradictory, the two approaches tend towards emergentism. Namely, a dialogic perspective presupposes the existence of the elements of culture, competence and IC which a differentialist perspective assumes while at the same time the approach introduces new features to the notions under discussion and consequently changes the balance and quality of the concepts and their components. Thus, the two perspectives permeate each other, which points to an evolving nature of the local intercultural discourse. However, even if there are signs of a schematic and liquid approach towards culture, competence and IC in some research, the national discourse is rather modular with its descriptions of the three concepts as sets of either dependent or independent faculties functioning as fixed attractors defining the cores of these notions. At the same time, the understanding of culture, competence and IC within the two perspectives is internally consistent, i.e. the three concepts are understood in a similar way within a single perspective. Therefore, global and local discourses appear to be two-fold, i.e. while the former reveals a more holistic approach to culture, competence and IC, the latter seems to stay unaffected by this trend. In other words, if IC is viewed from a complexity perspective, its state space in global discourse is more extensive than in the local milieu, with more dynamicity in the system's fluctuations among attractor states characterizing international intercultural research. This difference at the macro level can be related to discrepancies between global and local discourses at the micro level, whereby the notions of culture and competence are defined in a more schematic and generic manner in the former than in the latter. 
While current incongruities between global and local approaches could be attached to particular evolutionary paths each discourse has followed, the way culture, competence and IC are understood and researched in the future remains to be seen. Undoubtedly, though, possible interplays between centripetal and centrifugal forces influencing IC will have a considerable impact on further research directions.

Finally, the discrepancy between national and international discourses may result from little intercultural communication and interface between global and regional contexts, as presented in the above analysis. Thus, it seems that bridging the communication gap between researchers is another challenge that the intercultural paradigm faces.

Clearly, the need to improve communication among scholars is justified by the necessity to devise an approach that would capture "transnational connections and subnational localisations" (Risager 2007: 2), or facilitate greater interpenetration between local and global discourses which currently appear to exist alongside rather than within each other. In other words, the absence of a paradigm operating at micro- or/and macro-levels and bridging national and international discourses is the very reason why communication among researchers is not as fluent as it might be. For one thing, in the global vs. local perspective on IC emphasized throughout the article national discourses are often excluded from a discussion. Thus, we propose that a possible way to solve the problem is to move beyond the local-or-the-global approach towards a holistic model in which national discourses are "inclusive rather than exclusive" (Risager 2007: 236), and which shows the relation between language and culture as intricate and multidimensional (Risager 2007: 2). And we argue that complexity theory, with its focus on multifaceted nature of concepts, reciprocity of relations, levels and scales of development, offers a sound foundation upon which such a solution could be built.

\section{References}

Aleksandrowicz-Pędich, Lucyna 2006: Rozwijanie kompetencji interkulturowej na studiach biznesowych. Propozycje programowe. Białystok: Wydawnictwo UwB.

Ambrosewicz-Jacobs, Jolanta 2004: Tolerancja. Jak uczyć siebie i innych. Kraków: Stowarzyszenie Villa Decius.

Baker, Will 2015: Cultural awareness and intercultural awareness through English as a lingua franca: from research to classroom practice. Paper presented at Intercultural Communicative Competence in Action Symposium, Sussex, University of Sussex.

Bakhtin, Mikhail 1981: The Dialogic Imagination: Four Essays. Austin and London: University of Texas Press.

Białek, Michał 2009: Kształcenie międzykulturowe w edukacji językowej. Wrocław: Oficyna Wydawnicza Atut.

Bandura, Ewa 2007: Nauczyciel jako mediator kulturowy. Kraków: Wydawnictwo Tertium.

Barsalou, Lawrence 1999: Perceptual symbol systems. In Behavioral and Brain Sciences 22, 577-660.

Barsalou, Lawrence 2003: Abstraction in perceptual symbol systems. In Philosophical Transactions of the Royal Society of London: Biological Sciences 358, 1177-1187.

Barsalou, Lawrence 2008: Cognitive and neural contributions to understanding the conceptual system. In Current Directions in Psychological Science 17, 91-95.

Barsalou, Lawrence 2009: Simulation, situated conceptualization, and prediction. In Philosophical Transactions of the Royal Society of London: Biological Sciences 364, 1281-1289.

Barsalou, Lawrence 2016: Situated conceptualization: Theory and application. In Coello, Yann/Fischer, Martin (eds.), Foundations of embodied cognition. East Sussex, UK: Psychology Press, 1-17.

Bauman, Zygmunt 2004: Identity. Cambridge: Polity Press.

Bennett, Milton J. 1986: A developmental approach to training for intercultural sensitivity. In International Journal of Intercultural Relations 10(2), 179-196.

Białek, Michał 2009: Kształcenie międzykulturowe w edukacji językowe. Wrocław: Oficyna Wydawnicza Atut.

Bruner, Jerome Seymor 1973: Beyond the information given: Studies in the psychology of knowing. Oxford, England: W. W. Norton.

Byram, Michael 1997: Teaching and Assessing Intercultural Communicative Competence. Clevedon: Multilingual Matters. 
Byrnes, Heidi 2006: Perspectives. Interrogating communicative competence as a framework for collegiate for foreign language study. In Modern Language Journal 90, 244-256.

Chen, Guo-Ming 2014: Intercultural Communication Competence: Summary of 30-year Research and Directions for Future Study. In Dai, Xiaodong/Chen, Guo-Ming (eds.), Intercultural Communication Competence: Conceptualization and its Development in Cultural Contexts and Interactions. Newcastle upon Tyne: Cambridge Scholars Publishing, 14-40.

Collier, Mary Jane 1989: Cultural and intercultural communication competence: Current approaches and directions for future research. In International Journal of Intercultural Relations 13, 287-302.

Deardorff, Darla K 2006: The Identification and Assessment of Intercultural Competence as a Student Outcome of Internationalization at Institutions of Higher Education in the United States. In Journal of Studies in International Education 10, 241-266.

Deardorff, Darla K. (ed.) 2009: The SAGE Handbook of Intercultural Competence. Thousand Oaks, CA: SAGE Publications.

Deardorff, Darla K. 2011: Assessing intercultural competence. In New Directions for Institutional Research 149, 65-79.

Dervin, Fred. 2010: Assessing intercultural competence in Language Learning and Teaching: a critical review of current efforts. In Fred Dervin/Suomela-Salmi, Eija (eds.), New Approaches to Assessment in Higher Education. Bern: Peter Lang, 157-173.

Dervin, Fred 2011: A plea for change in research on intercultural discourses: A 'liquid' approach to the study of the acculturation of Chinese students. In Journal of Multicultural Discourse, 6 (1), 37-52.

Dobrowolska, Barbara 2009: Kompetencje międzykulturowe uczniów jako funkcja rozumienia problematyki wielokulturowości i świadomość jej roli u nauczyciela. Z pogranicza praktyki i teoretycznej refleksji. In Dąbrowa, Ewa/ Markowska-Manista, Urszula (eds.), Między kulturami. Edukacja w wielokulturowej rzeczywistości. Radom-Warszawa: Wydawnictwa Naukowe ITE PIB, 62-72.

Fantini, Alvino/Tirmizi, Aqeel 2006: Exploring and Assessing Intercultural Competence. World Learning Publications Paper 1. [online]. http://digitalcollections.sit.edu/cgi/viewcontent.cgi?article=1001\&context=worldlearning_publications.

Foncha, John Wankah/Sivasubramaniam, Sivakumar 2014: The Links between Intercultural Communication Competence and Identity Construction in the University of Western Cape (UWC) Community. In Mediterranean Journal of Social Sciences 5(10), 376-385.

Jabłońska, Urszula 2008: Nowe wyzwania: Zespoły międzykulturowe. In GFMP Management Focus 14, 17-19.

Jastrzębska, Elżbieta 2005: Edukacja interkulturowa przyszłych nauczycieli języka francuskiego. Uniwersytet Zielonogórski 3.

Kealey, Daniel J. 1989: A study of cross-cultural effectiveness: Theoretical issues, practical applications. In International Journal of Intercultural Relations 13, 387-428.

Komorowska, Hanna 1996: Nowe tendencje w pracach programowych Rady Europy. Koncepcje celów nauczania języków obcych. In Języki Obce w Szkole 2, 109-115.

Komorowska, Hanna 1999: Metodyka nauczania języków obcych. Warszawa: Wydawnictwa Szkolne i Pedagogiczne.

Kramsch, Claire 2009: Cultural perspectives on language learning and teaching. In Knapp, Karlfried/Seidlhofer, Barbara (eds.), Handbook of Applied Linguistics. Berlin: Mouton de Gruyter, 219-245.

Kramsch, Claire 2010: Language and Culture. In Simpson, James (ed.), Routledge Handbook of Applied Linguistics. New York: Routledge, 305-317.

Kramsch, Claire 2011: The symbolic dimensions of the intercultural. Language Teaching (44)3, 354-367.

Larsen-Freeman, Diane/Cameron, Lynne 2008: Complex Systems and Applied Linguistics. Oxford: Oxford University Press.

Larzén, Eva 2005: In pursuit of an intercultural dimension in EFL-teaching. Exploring cognitions among FinlandSwedish comprehensive school teachers. Åbo: Åbo Akademi University Press.

Liu, Shuang 2012: Rethinking intercultural competence: Global and local nexus. In Journal of Multicultural Discourses, 1-7 [online].doi: 10.1080/17447143.2012.693085.

Majewska, Renata 2014: Rozwój kompetencji dyskursywnej na przykładzie porównań interkulturowych. Sprawozdanie z badań przeprowadzonych w klasach dwujęzycznych z językiem hiszpańskim. In Języki Obce w Szkole 2, $37-44$.

Matsuo, Catherine 2012: A critique of Michael Byram's Intercultural Communicative Competence Model from the perspective of model type and conceptualization of culture. In Fukuoka University Review of Literature \& Humanities 44(2), 347-380. 
Matsuo, Catherine 2014: A Dialogic Critique of Michael Byram's Intercultural Communicative Competence Model: Proposal for a Dialogic Pedagogy [online]. http://www.academia.edu/14378676/A_Dialogic_Critique_of_Michael_Byrams_Intercultural_Communicative_Competence_Model_Proposal_for_a_Dialogic_Pedagogy.

McBride, Kara/Gu, Jingyun. 2015. Do the Folk Believe that They Can Speak Their Way into Interculturality? In Rozbicki, Michał Jan (ed.), Perspectives on interculturality: the construction of meaning in relationships of difference. New York: Palgrave Macmillan, 237-256.

Mihułka, Krystyna 2010: Trening interkulturowy na lekcji języka obcego a rozwój sprawności mówienia. In Pawlak, Mirosław/Waniek-Klimczak, Ewa (eds.), Mówienie w języku obcym - sukcesy i porażki uczenia się i nauczania. Poznań, Kalisz, Konin: Wydział Pedagogiczno-Artystyczny UAM w Poznaniu i PWSZ w Koninie, 153-163.

Mihułka, Krystyna 2012: Rozwój kompetencji interkulturowej w warunkach szkolnych. Mity a polska rzeczywistość. Rzeszów: Wydawnictwo Uniwersytetu Rzeszowskiego.

Mihułka, Krystyna 2014: Dylematy współczesnej glottodydaktyki: język - kultura, interlingwalizm - interkulturowość. In Języki: obce w szkole 3, 78-87.

Moeller, Aleidine Kramer/Nugent, Kristen 2014: Building intercultural competence in the language classroom. Faculty Publications: Department of Teaching, Learning and Teacher Education [online]. http://digitalcommons.unl.edu/ teachlearnfacpub/161.

Nikitorowicz, Jerzy 2013: Kompetencje do komunikacji międzykulturowej w aspekcie tradycyjnej wielokulturowości regionu i procesów migracyjnych. Wprowadzenie w realizowaną problematykę. In Nikitorowicz, Jerzy/Sobecki, Mirosław/Danilewicz, Wioleta/Muszyńska, Jolanta/Misiejuk, Dorota/Bajkowski, Tomasz (eds.), Kompetencje do komunikacji międzykulturowej w aspekcie wielokulturowości regionu i procesów migracyjnych. Warszawa: Wydawnictwo Akademickie Żak, 9-19.

Owczarek, Dorota 2004: Kształcenie kompetencji interkulturowej on-line. Projekt przeprowadzony w KJO w Poznaniu w ramach programu Democracy Education Exchange Project autorstwa Emily Abbot. In Neofilolog 25, 43-49.

Rapacka, Sylwia 2009: Kształcenie kompetencji interkulturowych uczestników procesu dydaktycznego poprzez rozwój komunikacji językowej [online]. http://www.kms.polsl.pl/prv/spnjo/referaty/rapacka.pdf

Risager, Karen 2007: Language and Culture Pedagogy. Clevedon: Multilingual Matters.

Rygg, Kristin. 2014: Intercultural Training: Learning to avoid treading on other people's toes or experience walking in other person's shoes. In Scandinavian Journal of Intercultural Theory and Practice 1(1), 1-14.

Sobieraj, Iwona (ed.) 2012: Kompetencje informacyjno-komunikacyjne i międzykulturowe w gospodarce. Warszawa: Wydawnictwo Naukowe Scholar.

Sorrells, Kathryn 2014: Intercultural Praxis: Transforming Intercultural Communication Competence for the 21st Century. In Dai, Xiaodong/Chen, Guo-Ming (eds.), Intercultural Communication Competence: Conceptualization and its Development in Cultural Contexts and Interactions. Newcastle upon Tyne: Cambridge Scholars Publishing, 144-169.

Spitzberg, Brian/Changnon, Gabrielle 2009: Conceptualizing Intercultural Competence. In Deardorff, Darla K. (ed.), The SAGE Handbook of Intercultural Competence. Thousand Oaks, CA.: SAGE Publications, 2-52.

Spitzberg, Brian/Cupach, Willaim. R 1984: Interpersonal communication competence. Beverly Hills, CA: Sage.

Strugielska, Ariadna/Piątkowska, Katarzyna. 2017: A plea for a socio-cognitive perspective on the language - culture - cognition nexus in educational approaches to intercultural communicative competence. In Review of Cognitive Linguistics 15(1), 224-252.

Szczurek-Boruta, Alina. 2013: Nauczyciele i kształtowanie kompetencji interkulturowej uczniów. In Pogranicze. Studia Społeczne 21, 155-169.

Thompson, Evan/Varela, Francisco J. 2001: Radical Embodiment: Neural Dynamics and Consciousness. In Trends in Cognitive Sciences 5(10), 418-425.

Tomasello, Michael 2003: Constructing a Language: A Usage-Based Theory of Language Acquisition. Harvard: Harvard University Press.

Tournebise, Céline 2012: The place for a renewed interculturality in Finnish higher education. In IJE4D Journal 1, 103-116.

UNESCO 2011: The Cultural Diversity Programming Lens: A practical tool to integrate culture in development-Pedagogical guide. Paris: UNESCO [online]. http://www.unesco.org/new/en/culture/themes/culture-and-development/ the-cultural-diversitylens/

UNESCO 2013: Intercultural Competences: Conceptual and Operational Framework. Paris: UNESCO.

Wąsikiewicz-Firlej, Emilia/Szczepaniak-Kozak, Anna/Lankiewicz, Hadrian (eds.). 2012: Interkulturowość, kreatywność, refleksyjność w dydaktyce języków obcych. Piła: Państwowa Wyższa Szkoła Zawodowa w Pile.

Więcek-Janka, Ewa 2011: Komunikacja międzykulturowa. In Marketing i Rynek 4, 1-11. 
Wilczyńska, Weronika 2005: Czego trzeba do udanej komunikacji interkulturowej?. In Mackiewicz, Maciej (ed.), Dydaktyka języków obcych a kompetencja kulturowa i komunikacja interkulturowa. Poznań: Wydawnictwo Wyższej Szkoły Bankowej, 15-26.

Zarzycka, Grażyna 2001: Typy zakłóceń w komunikacji międzykulturowej. In Hrabajska, Grażyna (ed.), Język w komunikacji 3. Łódź: WSHE Łódź, 243-258.

Żydek-Bednarczuk, Urszula 2012: Kompetencja międzykulturowa w nauczaniu języka polskiego jako obcego. In Postscriptum polonistyczne 2(10), 19-30. 